\title{
A Method for Determining Customers' Energy Shrinkage Cost
}

\author{
CONNY KURNIAWAN WACHJOE, HERMAGASANTOS ZEIN, SITI SAODAH
}

\author{
Politeknik Negeri Bandung, Indonesia \\ Email: ck_wachjoe@polban.ac.id
}

Received 10 Februari 2020| Revised 26 Februari 2020| Accepted 12 Juni 2020

\begin{abstract}
ABSTRAK
Penyusutan energi adalah salah satu komponen biaya-biaya listrik yang harus dibayar oleh pelanggan-pelanggan pada tegangan sistem dari jaringan yang berbeda, jaringan tegangan tinggi, sedang dan rendah. Meskipun biaya bahan bakar campuran adalah sama untuk semua pelanggan, alokasi kerugian berbeda untuk setiap jaringan tersebut. Makalah ini mengusulkan suatu metode untuk menentukan alokasi biaya penyusutan energi untuk pelanggan-pelanggan dalam suatu model rangkaian ekivalen, dengan beban dikumpulkan pada setiap jaringan. Formulasi-formulasinya diturunkan untuk mendapatkan alokasi kerugian yang adil di antara pelanggan-pelanggan berdasarkan hukum-hukum listrik. Hasil simulasi menunjukkan bahwa alokasi biaya penyusutan energi adalah 31\%, 33\% dan 36\% untuk pelanggan tegangan tinggi, sedang dan rendah. Selain itu, efisiensi jaringan akan mempengaruhi total biaya penyusutan energi. Jika perhitungan kerugian daya menggunaka metode Aliran Daya Optimal, maka metoda ini dapat mengurangi kerugian sebesar $\pm 3 \%$ atau setara dengan pengurangan biaya penyusutan energi sebesar $16 \%$.
\end{abstract}

Kata kunci: komponen biaya-biaya listrik, tegangan sistem, model rangkaian ekivalen, hukum-hukum listrik, alokasi biaya kerugian energi.

\begin{abstract}
Energy shrinkage is one component of electrical costs that must be paid by customers on the system voltage in different networks, high, medium, and low voltage networks. Although the fuel-mix costs are flat for all customers, loss allocation is different for each network. This paper proposes a method for determining the cost allocation of energy shrinkage to customers in an equivalent circuit model, with the loads collected for each network. Formulations are derived to get a fair allocation of losses among customers based on electric laws. The simulation results show that the cost allocation of energy shrinkage is 31\%, 33\%, and $36 \%$ for high, medium, and low voltage customers. Besides, network efficiency will affect the total cost of energy shrinkage. If power losses calculation uses the Optimal Power Flow method, it can reduce power losses by $\pm 3 \%$ or equivalent to a reduction in the cost of energy shrinkage of $16 \%$.
\end{abstract}

Keywords: component of electrical costs, system voltage, eqivqlent sircuit model, electric laws, cost allocation of energy shrinkage 


\section{INTRODUCTION}

An electric power system consists of three components, power plant, transmission, and distribution. Transmission networks have two categories: high voltage (HV) and medium voltage (MV) networks. While the distribution network distributes electrical energy with a low voltage (LV), these three networks will cause electrical power losses. The network system should have high reliability, so the customers' power delivered from the generators will be received safely as studied by William (William, 2012). Electric currents that flow in the transmission network will cause losses due to the resistance of the line conductor as in (James, 2014). The current flows in the distribution networks will also pass to the transmission networks. The losses in these networks have been elaborated successfully by (Lumona, 2014) (Conejo, 2002) (Shahzad, 2015).

Analysis of loss problems with four allocation rules has been studied by (Bergantiños, 2017). The paper presents a comparative analysis of the different standards by analyzing their behavior concerning a set of principles set forth by the European Union. The determination of transmission loss allocation through various practical algorithms has been reviewed by (Yiasemi, 2017). Losses in the power system are quite significant (generally around 9\%) that can be optimized. In line with this is the study presented by (Khosravi, 2018), his methodology is the use of generator contributions and loads in complex power injected into the network.

On the other hand, to determine energy shrinkage (ES) in the electric network, experts also received attention. Among them are (Daniel, 2019) (IEC, 2007) (Soham, 2012), who have successfully proposed to the network efficiency through a concept and its calculation. Energy efficiency in the transmission network is essential to consider in reducing the Energy Shrinkage Cost (ESC). It has received serious attention from electric power experts. One of them is a publication by Enshaee (Enshaee, 2018). That presents a clear concept to calculate energy efficiency in the transmission network. An effort to minimize power losses in transmission has been successfully described by Anyaka (Anyaka, 2014). The use of the Optimal Power Flow (OPF) method to obtain minimal losses has recommended (IEC, 2007). This effort is as an incentive to customers because the ESC will be lower.

Another study for the radian distribution system has been presented by (Sharma, 2017). Loss allocation is determined by a sequential approach using the Shapley Value Technique. It has succeeded in separating losses to be allocated to bilateral contracts. Separating losses using the Decomposition Technique has been proposed by (Hermagasantos, 2020). The methodology uses Kirchhoff's laws and superposition technique. The impedance load represents the power load of each node. Then a new bus impedance matrix is formed so that the superposition technique can be applied.

The effort to reduce the cost of energy losses is also one of the attention focus of electrical engineering experts. It must involve the fuel cost in addition to reducing losses so that the optimal power flow should consider the correlation between the fuel costs and transmission losses. The comprehensive discussions about the ESC that analyze the relation between fuel and transmission losses have been presented by (Hermagasantos, 2018) (Paul, 2010). The results have discussed that location and fuel prices of a power plant can influence the cost of energy losses. Whereas the other papers, as in (Conny, 2020) (Wakefield, 1997), have succeeded in providing a fundamental principle of the relationship between fuel and loss in the context of the electric power market. 
This paper focuses on the ESC that must be paid by each customer on the different system voltages in context integrated power system. There are three voltage levels considered, i.e., high, medium, and low voltage (LV) networks. The power network is simplified as an equivalent circuit model. It collects all loads on one bus for each network. Then formulations are mathematically derived to obtain an allocation of losses for a customer at each voltage level. Furthermore, the energy costs are determined through optimal power flow calculation. Therefore, the costs of the ES among customers are easy to be calculated.

\section{METHODS}

A power system model is an approach to derive ES for all loads at each network, and every network has the same system voltage. After determining the electric energy cost (EEC) from the fuel-mix value is continued to derive the ESC formulations mathematically in the model.

\subsection{Problem formulation}

The ES in the network is one of the cost components that customers must pay at each voltage level. These customers must bear ES costs according to their location on the network. The customers at LV will incur ES costs on high, medium, and LV networks as a result of the currents across those networks. Although the electric energy cost is the same, the minimization of mixed fuel from all power plants will contribute less energy loss. However, the electrical energy cost will be different for each customer as the effect of ES differs among customers at each voltage level.

Consequently, the increase in ES that occurs in each network at a system voltage will increase the EEC's customers. The power system has many lines, and customers scatter on buses, among high, medium, and LV networks, as described by (William, 2012). The ES allocation problems will be able to be solved if the power system network is simplified. Figure 1 visualizes a proposed power system model to illustrate the problem formulation.

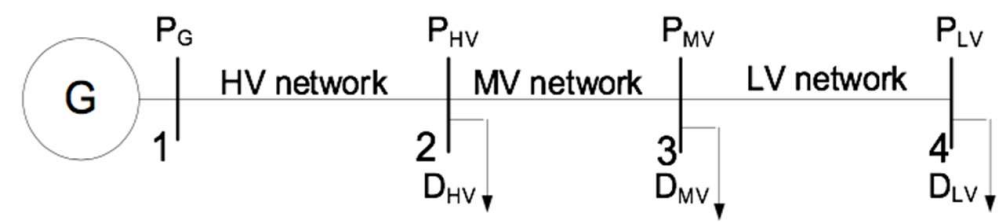

HV customers HV customers LV customers

Figure 1. Power System Model

In this model, all the power generated $\left(P_{G}\right)$ by the generators represented by a one-unit generator, namely generator $\mathrm{G}$, in bus 1 , whereas all customers will receive the electric power from the bus 1 . The HV customers receive power DHV at bus 2; The MV customers receive power DMV at bus 3, while the LV customers receive power DLV at bus 4, where DLV=PLV. So, Equation (1) formulates the power balance of the power system.

$$
P_{G}=D_{H V}+R_{H V}+D_{M V}+R_{M V}+D_{L V}+R_{L V}
$$

Based on Equation (1), the equations below show that separating power losses for each network can be formulated.

$$
R_{H V}=P_{G}-P_{H V}-D_{H V}
$$




$$
\begin{gathered}
R_{M V}=P_{H V}-P_{M V}-D_{M V} \\
R_{L V}=P_{M V}-D_{L V}
\end{gathered}
$$

Total network losses are the sum of the power loss for each type of customer as in (James, 2014). The percentage of power losses for each customer type is determined based on the total delivered power (PG) or total demand ( $D=D H V+D M V+D L V)$. If the calculation of the percentage of losses for each type of customer considers aggregate demand (D) as the basis, Equations (2), (3), and (4) calculate the percentage loss of each type of customer.

$$
T R_{H V}(\%)=R_{H V}(\%)+R_{M V}(\%)+R_{L V}(\%)
$$

From Equations (2), (3), and (4), we can define the total percentage power loss as formulated in Equation (6).

$$
T R_{H V}(\%)=R_{H V}(\%)+R_{M V}(\%)+R_{L V}(\%)
$$

Meanwhile, Equations (2), (3), and (4) represent the losses of each line based on the individual input power. Accordingly, the Equations (7), (8), and (9) are used to calculate the percentage of losses for each line. These equations use different basis, namely $P_{H V}$ for $\mathrm{HV}, P_{M V}$ for MV and $P_{L V}$ for LV.

$$
\begin{aligned}
& R_{H V}^{\prime}=100 \frac{R_{H V}}{P_{H V}}(\%) \\
& {R^{\prime}}_{M V}=100 \frac{R_{M V}}{P_{M V}}(\%) \\
& R_{L V}^{\prime}=100 \frac{R_{L V}}{P_{L V}}(\%)
\end{aligned}
$$

Because of a different basis, the total percentage of energy loss as the summation of the Equations (7), (8), and (9) cannot be done. Therefore, this approach is not valid to represent power system loss.

\subsection{Electric Energy Cost}

Fuel is the only one that has a direct impact on the EEC. While the power systems have many power plants using the various kinds of fuel. To get the low fuel costs of all power plants of a power system, the power plants must operate optimally and meet the constraints of the power system. Thus, Equation (10) formulates the EEC, where the Fuel-Mix Cost is obtained from the results of OPF.

$$
\rho=\frac{\text { Fuel-Mix Cost }}{\text { Total Energy Production }}\left(\frac{\downarrow}{\mathrm{kWh}}\right)
$$

Where the $\operatorname{EEC}(\rho)$ is the same for all customers.

\subsection{Energy Shrinkage Cost}

Figure 2 shows that line losses $\left(\boldsymbol{P}_{\boldsymbol{R}}=\boldsymbol{P}_{\boldsymbol{G}}-\boldsymbol{P}\right)$ are bear by customer load $\left(\boldsymbol{D}_{\boldsymbol{K}}\right)$ and network load $\left(\boldsymbol{D}_{J}\right)$. The allocation of losses for customers and networks is closely related to the amount of $D_{K}$ and $D_{J}$, respectively. 




\section{Customer}

Figure 2. Electric Power Model with Customers

While energy production per hour is equal to the cost received on a customer bus at the same time interval, namely:

$$
\rho_{G} P_{G} H=\rho P H
$$

Where $\rho_{G}$ and $\rho$ are in US $\phi / k W h, \mathrm{P}_{\mathrm{G}}$ and $\mathrm{P}$ are in $\mathrm{MW}$, and $\mathrm{H}$ is in an hour. From Equation (12), the EEC at the customer bus is,

$$
\rho=\frac{P_{G}}{P} \rho_{G}
$$

Or,

$$
\rho=\rho_{G}+\rho_{R}
$$

Where $\rho_{R}$ is the energy shrinkage cost (ESC) in US $\phi / \mathrm{kWh}$ with the formulation is,

$$
\rho_{R}=\frac{P_{R}}{P} \rho_{G}
$$

Energy costs on a customer, in Equation (15), consist of the EEC and ESC as a result of customer load. However, the ESC has not considered the separation of losses between customers and networks. While the losses must be bear by the customer and network, the allocation of power losses must be done relatively between the customers and the electricity networks. For example, loss allocations are $\mathrm{P}_{\mathrm{RK}}$ and $\mathrm{P}_{\mathrm{RJ}}$ for customer and network, respectively. Equation (17) and (18) can be used to calculate the ESC for customer and network.

$$
\rho P_{R}=\left(P_{R K}+P_{R J}\right) \rho
$$

Or,

$$
\rho P_{R}=\rho_{R K} D_{k}+\rho_{R J} D_{j}
$$

Where,

$$
\begin{gathered}
\rho_{R K}=\frac{P_{R K}}{D_{K}} \rho \\
\rho_{R J}=\frac{P_{R J}}{D_{J}} \rho
\end{gathered}
$$

So, energy costs for the consumer are, 


$$
\rho_{k}=\rho+\rho_{\mathrm{Rk}}
$$

\subsection{Loss Separation}

From Figure 2 in section 2.3, the current is separated into two parts on the customer bus, namely the current flowing to the customer $\left(I_{k}\right)$ and the current flowing into the network ( $\mathrm{Ij}$ ). If the line resistance is $R$, the power losses in the line are,

$$
P_{R}=R\left|I_{k}+I_{j}\right|^{2}=R I^{2}
$$

Or,

$$
P_{R}=R\left(I_{k}^{2}+I_{j}^{2}+C I_{k} I_{j}\right)
$$

In Equation (21), there is still an inseparable loss. The un-separate of power loss will be separated using Equation (23).

$$
R C\left(I_{k} I_{j}\right)=P_{R}-R\left(I_{k}^{2}+I_{j}^{2}\right)
$$

Furthermore, the un-separate of power loss will be separated based on the current portion approach so that the following formula will calculate the power losses.

$$
P_{R K}=R I_{k}^{2}+\frac{I_{k}}{I_{k}+I_{j}}\left(P_{R}-R\left(I_{k}^{2}+I_{j}^{2}\right)\right)
$$

Or,

$$
P_{R K}=\frac{I_{k}^{2}}{I^{2}} P_{R}+\frac{I_{k}}{I_{k}+I_{j}}\left(P_{R}-\frac{P_{R}}{I^{2}}\left(I_{k}^{2}+I_{j}^{2}\right)\right)
$$

For $\mathrm{n}$ branching currents in Equation (25), the branching of the power losses for the ${ }^{\text {th }}$ current is,

$$
P_{R K}=\left\{\frac{I_{k}^{2}}{I^{2}}+\frac{I_{k}}{\sum_{i=1}^{n} I_{i}}\left(1-\frac{\sum_{i=1}^{n} I_{i}^{2}}{I^{2}}\right)\right\} P_{R}
$$

\section{RESULTS AND DISCUSSIONS}

\subsection{Results}

Figure 3 is an electric power system model consisting of the HV, MV, and LV customers. Which the system must serve a load of $20 \mathrm{MW}, 30 \mathrm{MW}$ and $50 \mathrm{MW}$ in HV, MV, and LV customers, respectively.

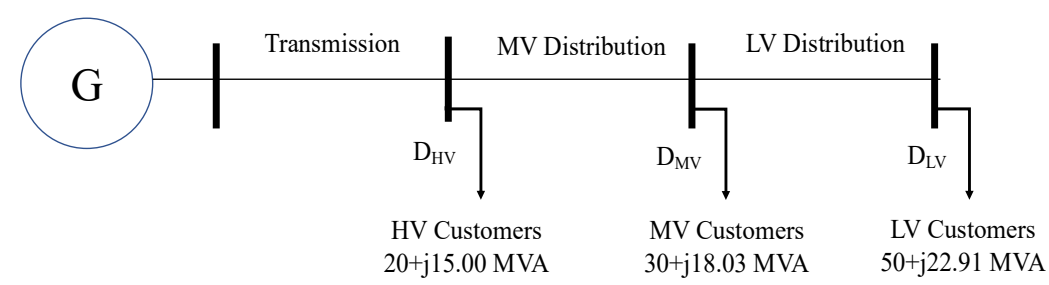

Figure 3. The Case of Electric Power System 
Table 1 shows the calculation result of complex power for each type of customer based on optimal power flow.

Table 1. Optimization Results for Each Customer

\begin{tabular}{|l|c|c|c|}
\hline No. & Customer & $\begin{array}{c}\text { Complex } \\
\text { Power (MVA) }\end{array}$ & $\begin{array}{c}\text { Apparent Power } \\
\text { (MVA) }\end{array}$ \\
\hline 1 & HV & $20+\mathrm{j} 15.00$ & 25 \\
\hline 2 & MV & $30+\mathrm{j} 18.03$ & 35 \\
\hline 3 & LV & $50+\mathrm{j} 22.91$ & 55 \\
\hline
\end{tabular}

From the calculation of the optimal power flow of the power system, the power losses of the $\mathrm{HV}$, the MV, and the LV networks can be seen in Table 2. Table 2 also shows two scenarios that represent transmission loss (\%) for each voltage level. In this case study, it is assumed that the percentage of network losses for HV, MV, and LV are depicted in Table 2.

Table 2. Power Loss in Electricity Network (\%)

\begin{tabular}{|l|l|l|l|l|}
\hline No. & Scenario & HV & MV & LV \\
\hline 1. & Base-Case Loss & 2 & 3 & 5 \\
\hline 2. & Optimal Loss & 1.5 & 2 & 3.5 \\
\hline
\end{tabular}

The impact of the ES on the ESC to customers can determine the ESC by substituting the EEC through Equation (15). The economic fuel-mix of the power plants that represent EEC is assumed to range from $3.4 \mathrm{US} \phi / \mathrm{kWh}$ to $5.8 \mathrm{US} \phi / \mathrm{kWh}$ (William, 2012) (DOE, 2018).

The simulation results to calculate the separating of losses and ESC for customers have been included in Tables 3 and 4.

Table 3. Simulation Results: Loss Separation

\begin{tabular}{|c|c|c|c|c|}
\hline \multirow{2}{*}{ Items } & \multicolumn{3}{|c|}{$\begin{array}{c}\text { ES bear by } \\
\text { customers }\end{array}$} & \multirow{2}{*}{ Total } \\
\cline { 2 - 4 } & HV & MV & LV & \\
\hline Loads & 20 & 30 & 50 & 100 \\
\hline ES of HV network & 0.21 & 0.00 & 0.00 & 0.21 \\
\hline ES of MV network & 0.51 & 0.97 & 0.00 & 1.48 \\
\hline ES of LV network & 1.01 & 1.91 & 5.00 & 7.92 \\
\hline Total Energy Loss & 1.73 & 2.88 & 5.00 & 9.60 \\
\hline
\end{tabular}

Table 3 presents the result of the ES's analysis, the proportion of ES in the HV, MV, and LV networks are $2 \%, 15 \%$, and $82 \%$, respectively. These values describe that the ES allocations are fair enough. On the other hand, the impact of the ESC on the networks based on the economic fuel-mix costs of the plants of $3.4 \mathrm{US} \phi / \mathrm{kWh}$ is presented in Table 4.

Table 4. Simulation Results: ESC of Customers

\begin{tabular}{|l|l|l|l|l|}
\hline \multirow{2}{*}{ Items } & \multicolumn{3}{|l|}{ ESC of Customers } & \multirow{2}{*}{ Total } \\
\cline { 2 - 5 } & HV & MV & LV & \\
\hline ESC of HV customers & 0.04 & 0 & 0 & 3.43 \\
\hline ESC of MV customers & 0.06 & 0.11 & 0 & 3.56 \\
\hline ESC of LV customers & 0.07 & 0.13 & 0.34 & 3.93 \\
\hline Total $(\$ / h)$ & 0.69 & 1.07 & 1.97 & 3.72 \\
\hline
\end{tabular}




\subsection{Discussions}

From Table 4 is obtained the proportion of ESC in the HV, MV, and LV networks, i.e., $31 \%$, $33 \%$, and $36 \%$, respectively. In the case of electric utilities, the total ESC is the US $\$ 3.72$ per hour earned from the customers.

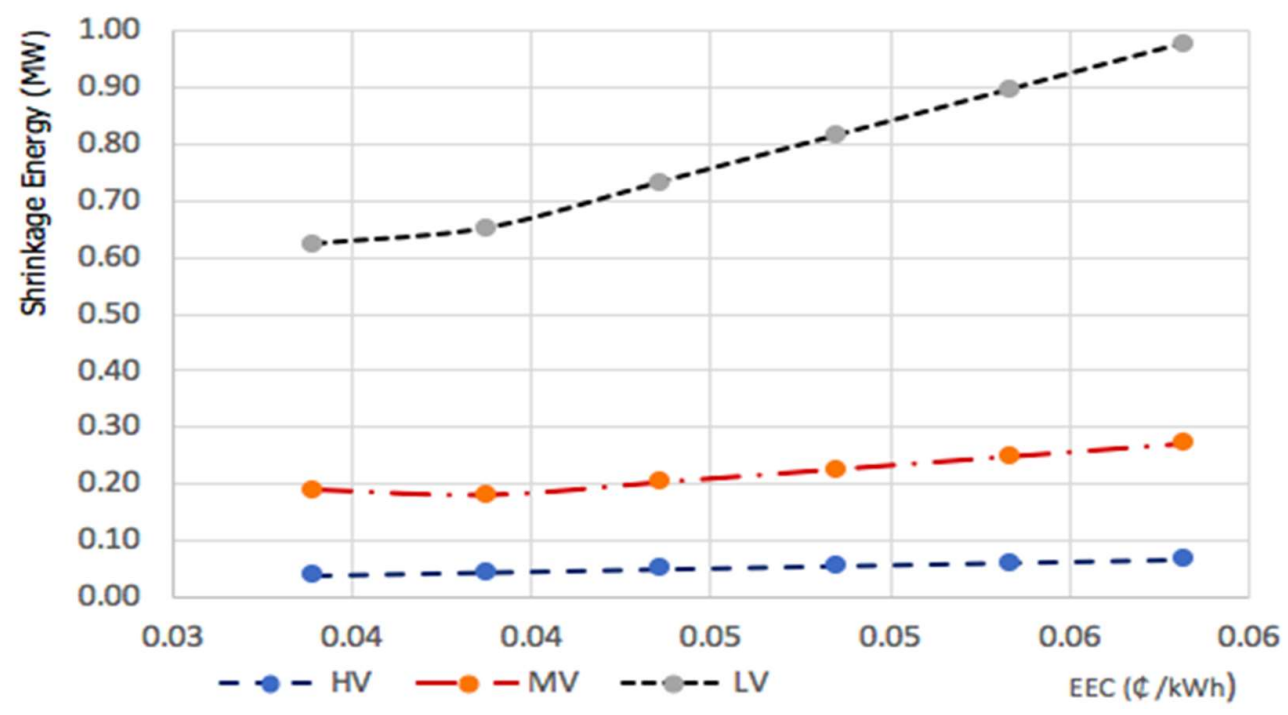

Figure 4. Energy shrinkage (ES) of networks vs electric energy cost (EEC) of power plants

Figure 4 shows that an increase in the EEC of the power plants leads to a linear rise proportionally of the ES of networks. The most significant portion of ES occurs in the LV network. It has raised EEC significantly for LV customers. A similar pattern occurs for total ESC, which increases proportionately to EEC of power plants, such as Figure 5.

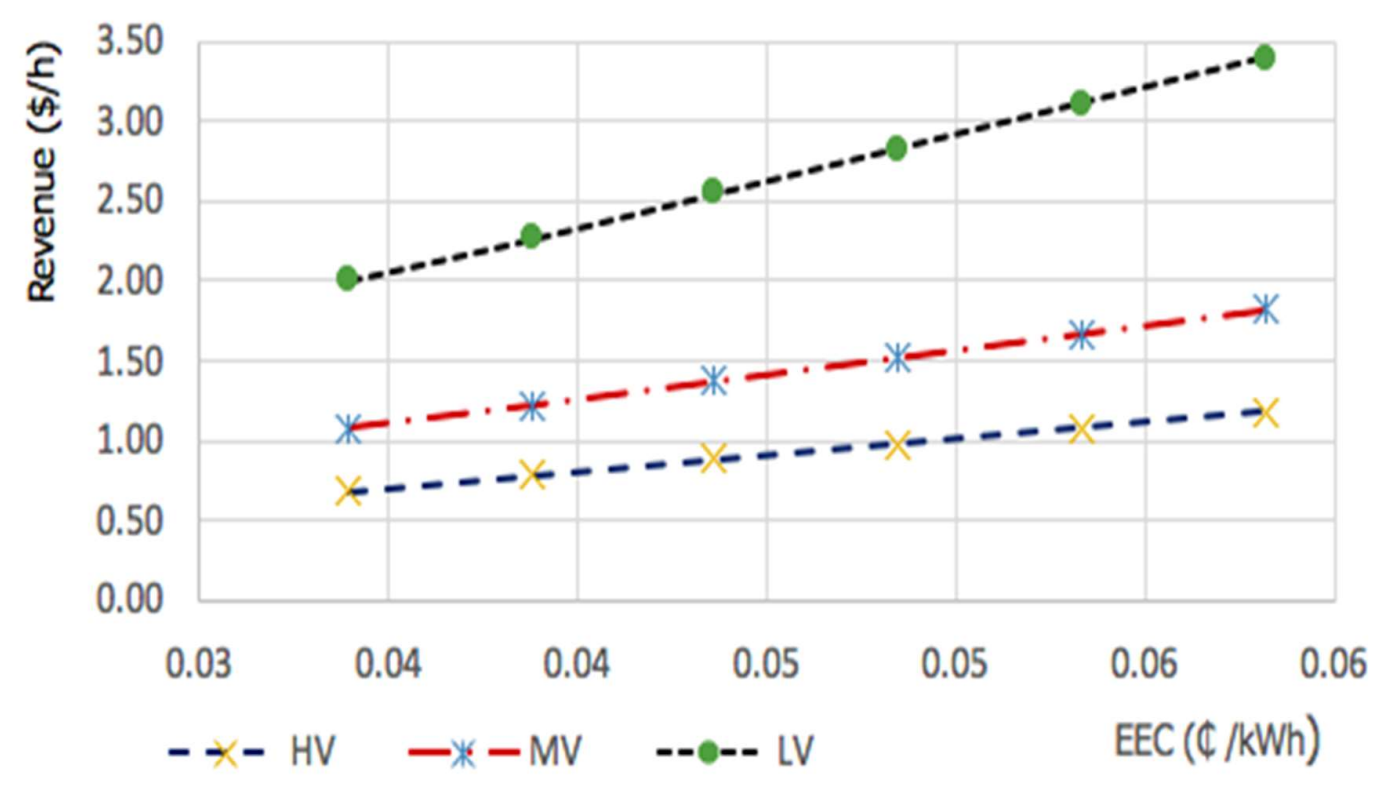

Figure 5. Total energy shrinkage cost (ESC) vs electric energy cost (EEC) of power plants 


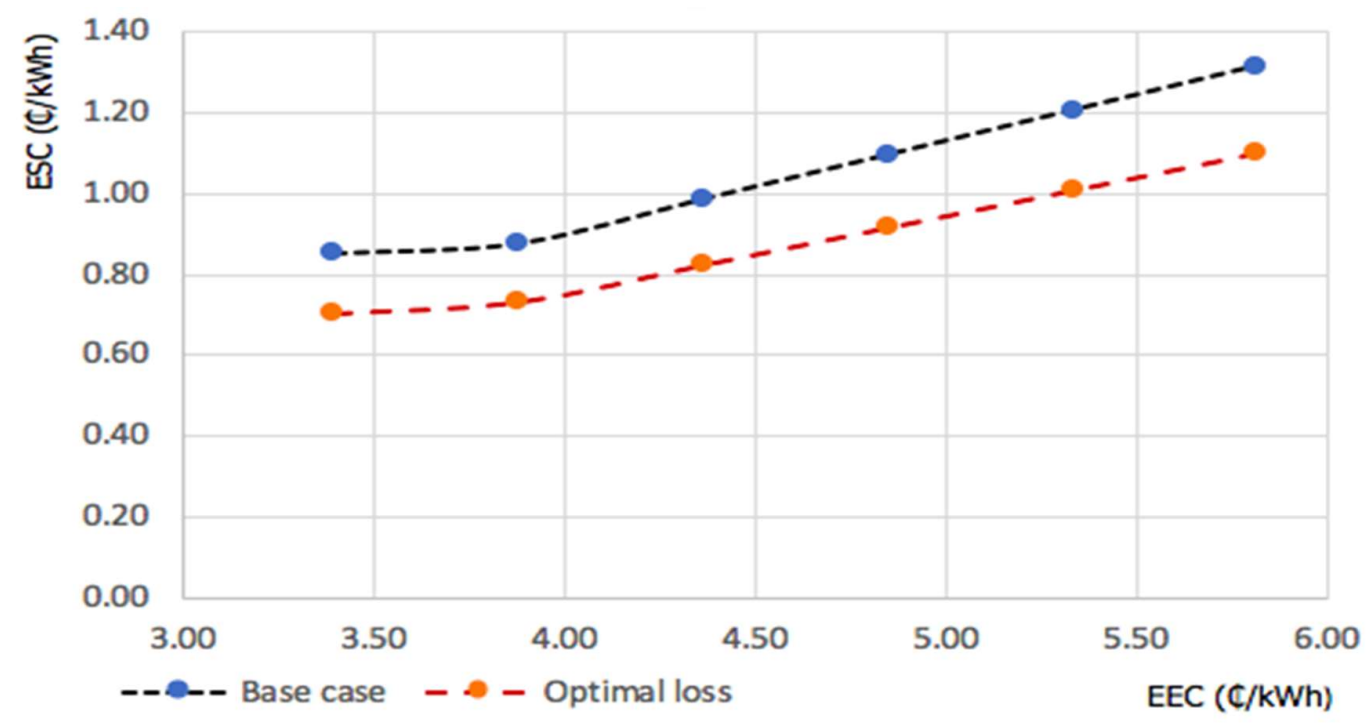

Figure 6. ESC vs EEC for two scenarios

The same curve pattern is obtained from both scenarios from the two simulation scenarios (Table 2). However, the optimized fuel-mix (see the red curve in Figure 6) has a lower ESC value. This value is due to the optimal EEC, and it results provide optimal losses more economical than the power losses of the base case scenario. This value is closely related to reducing the percentage loss of 3\% from the base-case scenario to the optimization scenario so that the optimal ESC is smaller, on average, of $16 \%$ than in the base-case ESC.

\section{CONCLUSION}

The proposed method has succeeded in determining the allocation of electrical energy costs for each customer, HV, MV, and LV customers. The methodology is to derive formulations from the equivalent circuit model approach of the power system. The simulation shows that the LV customers take the highest ES up to $82 \%$ of the total ES. While the proportion of the ESC in HV, MV and LV networks are $31 \%, 33 \%$, and $36 \%$, respectively. When A Loss reduction of the networks is about $3 \%$, from $10 \%$ (base case scenario) to $7 \%$ (optimal scenario), it has contributed to the reduction of ESC costs by an average of $16 \%$. An increase in network efficiency affects the lower allocating energy shrinkage for each customer. The method is very suitable, accurate, and practical to determine a fair allocation of electrical energy costs for each type of customer.

\section{REFFERENCES}

Anyaka, B. O., \& Olawoore, O.I. (2014). Minimization of Power Losses in Transmission Lines. IOSR Journal of Electrical and Electronics Engineering (IOSR-JEEE), 9(3), 23-29.

Bergantiños, G., González-Díaz, J., González-Rueda, Á. M., \& Córdoba, M. P. F. d. (2017). Loss allocation in energy transmission networks. Games Econ Behav, 102-110. 
Conejo, A. J., Arroyo, J. M., Alguacil, N., \& Guijarro, A. L. (2002). Transmission Loss Allocation: A Comparison of Different Practical Algorithms. IEEE Transactions on Power Systems, $17,571-576$.

Conny, K. W., \& Hermagasantos, Z. (2020). Fairness in Allocation of Transmission Losses to Bilateral Contracts with Superposition and Decomposition Techniques. International Journal on Energy Conversion, 8(1), 1-7. DOI: 10.15866/irecon.v8i1.18290

Daniel, M. B., \& Ebenhack, T. W. (2019). Energy Efficiency: Concepts and Calculations. 1st ed. Paperback ISBN: 9780128123164, Elsevier Science.

DOE. (2018). Annual Energy Outlook (AEO) Retrospective Review: Evaluation of AEO2018 and Previous Reference Case Projections 2007-2018.

IEC Document. (2007). Efficient Electrical Energy Transmission and Distribution

Enshaee, A., Yousefi, G. R., \& Ebrahimi, A. (2018). Allocation of transmission active losses through a novel power tracing-based technique. IET Generation Transmission Distribution. 1021-1028

Hermagasantos, Z., Annisa, S. K., \& Conny KW. (2020). Fuel Cost Optimization of The Power System by Involving All Operating Limits Based on The Developed Interior Point Algorithm. International Transactions on Electrical Energy System (ITEES), 30(5), 1-14 DOI: $10.1002 / 2050-7038.12337$

Hermagasantos, Z., Jangkung, R. \& Ahmad, D. M. (2018). Optimal Complex Power Production Cost in The Electric Power Market. In: International Conference on Sustainable Energy Engineering and Application (ICSEEA). 111-115. DOI:10.1109/icseea.2018.8627127

James, W. N., \& Susan, R. L. (2014). Electric Circuits. 10th ed. Australia: Pearson.

Khosravi, M., Monsef, H., \& Aliabadi, M. H. (2018). Approach for allocation of transmission loss based on contribution of generators and loads in injected complex power into network lines. IET Generation Transmission Distribution, 1245-1252

Lumona, T. L., Nwosu, M. O., Ezechukwu, A. O., Chijioke J. (2014). Overview of Losses and Solutions in Power Transmission Lines: Network and Complex Systems. ISSN 222 50603, 4(8), 24-31.

Paul, B. (2010). The Cost of Power Generation. Business Insights Ltd. Management Report.

Shahzad, S. B., Umair,E. M., Lodhi, U., Shan, U. H., Syed, N. M. G., \& Muhammad, A. J. (2015). Electric Power Transmission and Distribution Losses Overview and Minimization in Pakistan. International Journal of Scientific \& Engineering Research, April, 6 (4), 1108 1112. 
Soham, G. (2012). Loss Reduction and Efficiency Improvement: A Critical Appraisal of Power Distribution Sector in India. International Journal of Modern Engineering Research (IJMER), 2(5), 3292-3297.

Sharma, S., \& Abhyankar, A. R. (2017) Loss allocation of radial distribution system using Shapley value: A sequential approach. International Journal Electric Power Energy System, 88-95.

Wakefield, R. A., et.al. (1997). A Transmission Services Costing Framework. IEEE Transaction on Power System, 12(4), 622 - 628. DOI: 10.1109/59.589624

William, H. H., Jack, E. K., \& Steven M. D. (2012). Engineering Circuit Analysis. 8th ed. New York 10020, USA: The McGraw-Hill Companies Inc.

Yiasemi, Y., Ciornei, I., Asprou, M., \& Kyriakides, E. (2017). Near-real-time loss allocation methodology based on the power system states. IET Generation Transmission Distribution; 11(5), 1243-1250. DOI: 10.1049/iet-gtd.2016.1166 